\title{
Kajian Perbandingan Hasil Nilai Pengujian Berbasis Kertas dan Berbasis Komputer Sebagai Indikator Mengukur Kesiapan Peserta Tes Menghadapi Ujian Berbasis Komputer
}

\author{
Abd. Rahman Patta ${ }^{1}$, Hendriyati Eko B ${ }^{2}$, Iwan Suhardi ${ }^{3}$ \\ ${ }^{1}$ Prodi Teknik Komputer FT UNM, ${ }^{2}$ SMK N 1 Boyolali, ${ }^{3}$ Prodi PTIK FT UNM \\ abd.rahman.patta@unm.ac.id
2 hendriyati69@gmail.com \\ 3 iwan.suhardi@unm.ac.id
}

\begin{abstract}
Abstrak - Penelitian ini bertujuan untuk mengukur kesiapan peserta tes pada suatu sekolah dalam menghadapi ujian berbasis komputer. Penelitian ini dimulai dengan suatu kajian apakah ada perbedaan hasil skor penilaian peserta tes bila paket soal yang sama diujikan pada model pengujian yang tampilannya berbeda yaitu model Paper-Based Testing (PBT) dan Computer-Based Testing (CBT). Seperangkat paket soal dikembangkan untuk pembuatan model PBT dan menjadi basis data pada perangkat lunak CBT. Selanjutnya dilakukan uji statistik untuk dapat mengetahui apakah terdapat perbedaan yang signifikan antara hasil skor penilaian yang diperoleh dari hasil pengujian dengan model PBT dan CBT tersebut. Dari uji statistik tersebut dapat ditentukan tingkat kesiapan peserta tes pada suatu sekolah dalam menghadapi ujian yang berbasis komputer. Jika hasil uji statistik tidak diperoleh hasil perbedaan hasil skor penilaian kelompok PBT dan CBT, maka peserta tes pada sekolah tersebut dinyatakan telah siap menghadapi ujian berbasis komputer. Jika hasil uji statistik didapatkan adanya perbedaan hasil skor penilaian, selanjutnya dilihat besarnya rata-rata hasil skor penilaiannya. Jika besarnya rata-rata hasil skor penilaian kelompok PBT lebih rendah dari hasil skor penilaian kelompok CBT, maka peserta tes pada sekolah tersebut dinyatakan telah siap menghadapi ujian berbasis komputer. Namun, jika didapatkan besarnya rata-rata hasil skor penilaian kelompok PBT lebih tinggi dari hasil skor penilaian kelompok CBT, maka peserta tes pada sekolah tersebut dinyatakan belum siap menghadapi ujian berbasis komputer.
\end{abstract}

Kata Kunci : Paper-Based Testing, Computer-Based Testing, Skor Penilaian.

\section{Pendahuluan}

Peranan CBT mulai berangsur-angsur secara pasti menggantikan fungsi Paper Based Test (PBT) [1]. Tren penggunaan model pengujian CBT di lingkungan pendidikan diprediksi akan terus meningkat menggantikan model PBT [2]. Secara psikometrik hampir tidak ada kelebihan CBT dibandingkan dengan PBT. PBT dan CBT menggunakan jumlah butir yang sama untuk setiap peserta atau fix-length test. Walaupun mempunyai paradigma pengukuran estimasi kemampuan peserta tes yang sama, model PBT dan CBT mempunyai perbedaan yang mencolok dilihat dari konteks dan suasananya [3]. Ahli psikometri, seperti Rudner dan Grist, berpendapat bahwa parameter butir soal yang dipergunakan pada PBT mungkin tidak sesuai dengan tampilannya pada layar monitor komputer [4][5]. Perbandingan aspek konteks dan suasana antara model PBT dan CBT yang dihadapi peserta ujian disajikan pada Tabel 1 berikut ini:

Tabel 1. Perbandingan aspek konteks dan suasana Model PBT dan CBT

\begin{tabular}{|l|l|l|}
\hline $\begin{array}{l}\text { Konteks dan } \\
\text { Suasana }\end{array}$ & \multicolumn{1}{|c|}{ Model PBT } & \multicolumn{1}{c|}{ Model CBT } \\
\hline $\begin{array}{l}\text { Jumlah butir } \\
\text { soal dalam } \\
\text { jangkauan } \\
\text { pandangan mata }\end{array}$ & $\begin{array}{l}\text { Terdiri dari banyak } \\
\text { butir soal }\end{array}$ & $\begin{array}{l}\text { Biasanya hanya ada } \\
1 \text { (satu) butir soal } \\
\text { saja, bahkan untuk } \\
\text { butir soal yang } \\
\text { panjang harus di- } \\
\text { scroll. }\end{array}$ \\
\hline Alat bantu ujian & Kertas dan pensil & $\begin{array}{l}\text { Layar monitor, } \\
\text { CPU, keyboard, } \\
\text { mouse, dan speaker }\end{array}$ \\
\hline $\begin{array}{l}\text { Model } \\
\text { mengerjakan } \\
\text { butir soal }\end{array}$ & $\begin{array}{l}\text { Memberi tanda } \\
\text { pilihan soal jawaban } \\
\text { yang dianggap }\end{array}$ & $\begin{array}{l}\text { Memilih jawaban } \\
\text { yang dianggap } \\
\text { benar dengan mouse }\end{array}$ \\
\hline
\end{tabular}

\begin{tabular}{|l|l|l|}
\hline & benar dengan pensil & atau keyboard \\
\hline $\begin{array}{l}\text { Aspek } \\
\text { pengetahuan } \\
\text { dasar tentang } \\
\text { teknologi } \\
\text { informasi }\end{array}$ & Tidak diperlukan & Diperlukan \\
\hline $\begin{array}{l}\text { Faktor } \\
\text { kebiasaan } \\
\text { mengerjakan tes }\end{array}$ & & \\
\hline
\end{tabular}

Perbedaan konteks dan suasananya antara model pengujian PBT dan CBT, serta faktor kebiasaan dalam pengerjaan ujian dapat mempengaruhi secara psikologis pada saat mengerjakan butir soal ujian berbasis komputer. Pengaruh faktor kecemasan dan kegelisahan menjelang dan pada proses ujian dapat menyebabkan siswa tidak dapat fokus mengerjakan tes dengan baik ketika menggunakan model ujian berbasis komputer.

Seiring dengan peningkatan penetrasi peranan model pengujian CBT menggantikan PBT dalam lingkungan pendidikan, maka tingkat kesetaraan model pengujian BPT dan CBT perlu dianalisis lebih lanjut. Diperlukan juga kajian mekanisme pengukuran yang sederhana dan mudah diaplikasikan yang dapat berfungsi sebagai indikator tingkat kesiapan peserta tes di suatu sekolah dalam menempuh model pengujian berbasis komputer di masa mendatang.

\section{METODOLOGI}

Penelitian ini menggunakan gabungan metode pengembangan dan kajian kuantitatif. Metode pengembangan dilakukan untuk mengembangkan perangkat tes paket soal dan perangkat lunak CBT. Paket soal terdiri dari 40 (empat puluh) butir soal dengan materi diambil dari mata pelajaran Bahasa Indonesia Kelas X SLTA (SMA/SMK) sesuai dengan Kurikulum 2013. 
Karakter paket butir soal dibuat semirip mungkin antara model PBT dan CBT. Sebagaimana teknis pengerjaan model pengujian PBT, perangkat lunak CBT didesain agar responden dapat memilih nomor butir soal yang dikehendaki dan dapat meninjau ulang respon jawabannya jika ingin menggantinya.

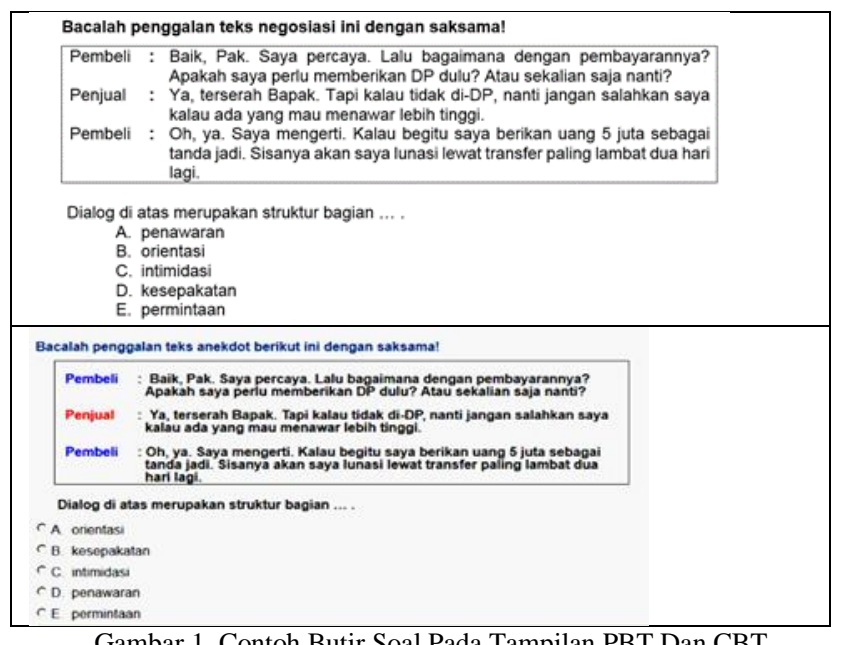

Gambar 1. Contoh Butir Soal Pada Tampilan PBT Dan CBT

Pada penelitian ini dilakukan eksperimen dengan membentuk 2 (dua) kelompok responden dengan jumlah masing-masing 100 (seratus) responden yang diasumsikan mempunyai kemampuan setara. Satu kelompok mengerjakan model pengujian PBT dan kelompok lainnya mengerjakan model CBT.

Pada model PBT, paket soal yang telah dikembangkan dicetak sebanyak jumlah responden yang diperlukan. Untuk model CBT, paket soal yang sudah dikembangkan dimasukkan ke dalam basis data perangkat lunak CBT. Model CBT yang dikembangkan menggunakan sistem client-server berbasis web yang dapat diakses melalui jaringan LAN. Setiap responden model CBT menggunakan 1 (set) peralatan komputer.

Hasil skor pengujian kelompok-kelompok responden tersebut selanjutnya dianalisis dengan perangkat SPSS untuk diuji secara statistik apakah terdapat perbedaan secara signifikan antara dua model pengujian tersebut. Hasil analisis luaran SPSS selanjutnya dievaluasi untuk menentukan tingkat kesiapan peserta menempuh tes berbasis komputer. Secara umum, bagan alur penelitian ini disajikan pada Gambar 2 berikut ini.

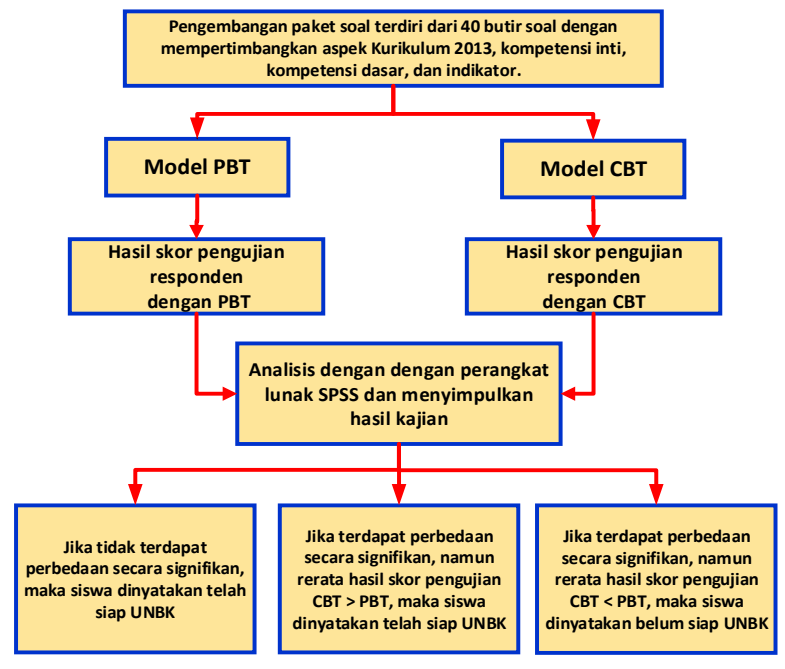

Gambar 2. Bagan Alur Penelitian

\section{HASIL PENELITIAN DAN PEMBAHASAN}

Setelah dilakukan proses pengujian, hasil skor pengujian yang didapatkan dari kelompok model pengujian PBT dan CBT disajikan pada Tabel 2 berikut.

Tabel 2. Hasil Skor Pada Model Pengujian PBT dan CBT

\begin{tabular}{|r|r|c|r|r|r|r|}
\hline \multicolumn{7}{|c|}{ HASIL SKOR PBT } \\
\hline SISWA & SKOR & SISWA & SKOR & \multicolumn{1}{|l|}{ SISWA } & SKOR \\
\hline 001 & 65 & 035 & 47,5 & 069 & 92,5 \\
\hline 002 & 62,5 & 036 & 62,5 & 070 & 92,5 \\
\hline 003 & 60 & 037 & 50 & 071 & 60 \\
\hline 004 & 55 & 038 & 62,5 & 072 & 97,5 \\
\hline 005 & 55 & 039 & 62,5 & 073 & 67,5 \\
\hline 006 & 67,5 & 040 & 87,5 & 074 & 95 \\
\hline 007 & 70 & 041 & 65 & 075 & 57,5 \\
\hline 008 & 92,5 & 042 & 52,5 & 076 & 77,5 \\
\hline 009 & 72,5 & 043 & 75 & 077 & 70 \\
\hline 010 & 85 & 044 & 32,5 & 078 & 92,5 \\
\hline 011 & 67,5 & 045 & 32,5 & 079 & 97,5 \\
\hline 012 & 60 & 046 & 92,5 & 080 & 62,5 \\
\hline 013 & 65 & 047 & 82,5 & 081 & 62,5 \\
\hline 014 & 72,5 & 048 & 82,5 & 082 & 55 \\
\hline 015 & 60 & 049 & 87,5 & 083 & 62,5 \\
\hline 016 & 65 & 050 & 95 & 084 & 75 \\
\hline 017 & 100 & 051 & 72,5 & 085 & 80 \\
\hline 018 & 70 & 052 & 77,5 & 086 & 57,5 \\
\hline 019 & 65 & 053 & 65 & 087 & 87,5 \\
\hline 020 & 62,5 & 054 & 47,5 & 088 & 75 \\
\hline 021 & 60 & 055 & 67,5 & 089 & 97,5 \\
\hline 022 & 60 & 056 & 97,5 & 090 & 77,5 \\
\hline 023 & 77,5 & 057 & 100 & 091 & 65 \\
\hline 024 & 70 & 058 & 67,5 & 092 & 52,5 \\
\hline 025 & 65 & 059 & 60 & 093 & 50 \\
\hline 026 & 70 & 060 & 67,5 & 094 & 70 \\
\hline 027 & 70 & 061 & 67,5 & 095 & 67,5 \\
\hline 028 & 62,5 & 062 & 67,5 & 096 & 82,5 \\
\hline 029 & 57,5 & 063 & 70 & 097 & 57,5 \\
\hline 030 & 60 & 064 & 95 & 098 & 60 \\
\hline 031 & 52,5 & 065 & 70 & 099 & 67,5 \\
\hline 032 & 47,5 & 066 & 60 & 100 & 70 \\
\hline 033 & 55 & 067 & 95 & & \\
\hline 034 & 52,5 & 068 & 87,5 & & \\
\hline & & & & & \\
\hline & & HASIL SKOR CBT & & \\
\hline SISWA & SKOR & SISWA & SKOR & SISWA & SKOR \\
\hline 001 & 20 & 035 & 67,5 & 069 & 30 \\
\hline 002 & 15 & 036 & 55 & 070 & 45 \\
\hline 003 & 25 & 037 & 47,5 & 071 & 60 \\
\hline 004 & 50 & 038 & 70 & 072 & 50 \\
\hline 005 & 75 & 039 & 60 & 073 & 52,5 \\
\hline 006 & 42,5 & 040 & 67,5 & 074 & 30 \\
\hline 007 & 55 & 041 & 65 & 075 & 30 \\
\hline 008 & 60 & 042 & 67,5 & 076 & 55 \\
\hline 009 & 57,5 & 043 & 55 & 077 & 40 \\
\hline 010 & 52,5 & 044 & 55 & 078 & 40 \\
\hline 011 & 55 & 045 & 62,5 & 079 & 47,5 \\
\hline 012 & 47,5 & 046 & 70 & 080 & 37,5 \\
\hline 013 & 32,5 & 047 & 65 & 081 & 45 \\
\hline 014 & 52,5 & 048 & 60 & 082 & 57,5 \\
\hline 015 & 55 & 049 & 57,5 & 083 & 47,5 \\
\hline 016 & 45 & 050 & 55 & 084 & 42,5 \\
\hline
\end{tabular}




\begin{tabular}{|l|r|l|r|r|r|}
\hline 017 & 37,5 & 051 & 55 & 085 & 52,5 \\
\hline 018 & 72,5 & 052 & 55 & 086 & 45 \\
\hline 019 & 52,5 & 053 & 55 & 087 & 42,5 \\
\hline 020 & 37,5 & 054 & 55 & 088 & 35 \\
\hline 021 & 37,5 & 055 & 77,5 & 089 & 45 \\
\hline 022 & 40 & 056 & 55 & 090 & 30 \\
\hline 023 & 50 & 057 & 47,5 & 091 & 42,5 \\
\hline 024 & 37,5 & 058 & 65 & 092 & 40 \\
\hline 025 & 37,5 & 059 & 72,5 & 093 & 52,5 \\
\hline 026 & 50 & 060 & 60 & 094 & 47,5 \\
\hline 027 & 52,5 & 061 & 60 & 095 & 37,5 \\
\hline 028 & 55 & 062 & 47,5 & 096 & 45 \\
\hline 029 & 52,5 & 063 & 47,5 & 097 & 55 \\
\hline 030 & 65 & 064 & 55 & 098 & 47,5 \\
\hline 031 & 52,5 & 065 & 15 & 099 & 87,5 \\
\hline 032 & 52,5 & 066 & 20 & 100 & 42,5 \\
\hline 033 & 22,5 & 067 & 10 & & \\
\hline 034 & 25 & 068 & 37,5 & & \\
\hline
\end{tabular}

Pengujian secara statistik perbandingan hasil pengujian dilakukan dengan program bantu SPSS. Metode yang dilakukan yaitu dengan uji $\mathrm{t}$ dua sampel bebas. Hasil keluaran SPSS disajikan pada Gambar 3 berikut.

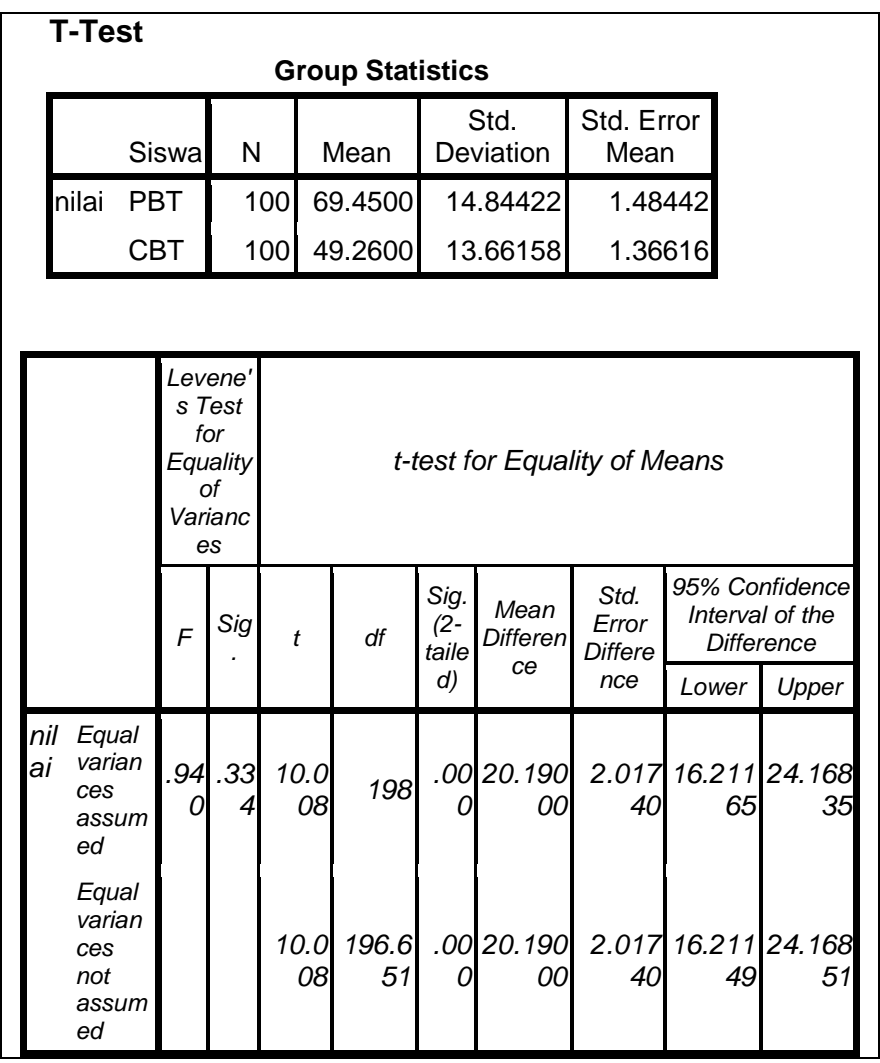

Gambar 3. luaran SPSS Skor Model Pengujian PBT dan CBT

Untuk menguji, apakah terdapat perbedaan hasil skor pengujian metode PBT dan CBT, terlebih dahulu dilakukan uji kesamaan varian. Uji kesamaan varian dilakukan dengan menggunakan nilai pengujian $\mathrm{F}$ atau pengujian Lavene. Angka $\mathrm{F}$ test yang mengasumsikan kedua varian sama adalah 0,940 dengan probabilitas (sig) sebesar 0,334. Oleh karena angka probabilitas > 0,05, maka H0 diterima dan Ha ditolak. Maka berarti bahwa tidak ada perbedaan varian hasil penilaian antara kelompok model pengujian PBT dan model CBT. Dengan tidak adanya perbedaan varian hasil penilaian antara kelompok model pengujian PBT dan model CBT, maka selanjutnya dilakukan uji rata-rata antara kedua model pengujian tersebut.

Membandingkan rata-rata hasil pengujian kelompok model pengujian PBT dan model CBT dilakukan dengan cara menggunakan angka $\mathrm{t}$ test yang mengasumsikan kedua varian sama (equal variances assumsed). Angka ini digunakan karena hasil analisis dengan menggunakan $\mathrm{F}$ test menunjukkan tidak adanya perbedaan varian antara kedua kelompok tersebut.

Langkah-langkah yang dilakukan untuk uji rata-rata model pengujian PBT dan CBT yaitu:

1. Merumuskan hipotesis penelitian

Ada perbedaan rata-rata hasil penilaian antara kelompok model PBT dan CBT

2. Merumuskan hipotesis operasional (hipotesis null dan alternatif)

$\mathrm{H}_{0}$ : Rata-rata hasil penilaian dengan model PBT dan CBT sama

$\mathrm{H}_{\mathrm{a}}$ : Rata-rata hasil penilaian dengan model PBT dan CBT tidak sama

3. Menentukan level kepercayaan yang digunakan

Level kepercayaan yang digunakan adalah $95 \%$ atau dengan menggunakan alpha 5\%.

4. Menentukan aturan pengambilan keputusan

Aturan dalam pengambilan keputusannya adalah menerima $\mathrm{H}_{0}$ jika $\mathrm{t}$ hitung lebih kecil daripada $\mathrm{t}$ tabel dan menolak $\mathrm{H}_{0}$ jika $t$ hitung lebih besar dari $t$ tabel. Berdasarkan $t$ tabel dengan alpha 5\% uji 2 arah atau 2,5\%; dan derajad kebebasan $\mathrm{df}=198$ diperoleh nilai $\mathrm{t}$ tabel sebesar 1.97202. Jadi keputusan yang diambil adalah menerima $\mathrm{H}_{0}$ jika $\mathrm{t}$ hitung lebih kecil dari 1.97202 dan menolak $\mathrm{H}_{0}$ jika t hitung lebih besar dari 1.97202 .

5. Menghitung thitung atau t statistik

Untuk menghitung nilai statistik digunakan program bantu SPSS, t hitung didapatkan 10.008

6. Pengambilan keputusan dan interpretasi hasil

Rata-rata perbedaan hasil penilaian antara model pengujian PBT dan CBT adalah 20,19 dengan deviasi standar 2,017. Hasil perhitungan $\mathrm{t}$ statistik menghasilkan nilai sebesar 10,008 dan sigifikansinya 0,0001 .

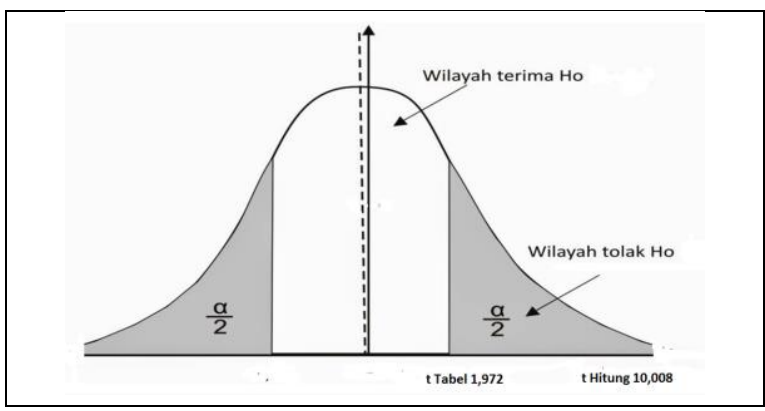

Gambar 4. Uji Hipotesis Two Tail Hasil Skor Pengujian

Dengan hasil signifikansi sebesar 0,001 bisa diambil keputusan untuk menolak H0 karena level signifikansi lebih kecil dari pada alpha $(0,025)$. Hasil perhitungan nilai t hitung $(10,008)$ ternyata jatuh di daerah penolakan, maka HO ditolak. Oleh karena itu Ha diterima. Artinya, dari hasil analisis dapat dinyatakan bahwa secara statistik hasil skor pengujian dari kedua metode tersebut (PBT dan CBT) berbeda untuk setiap butirnya.

Angka perbedaan rata-rata (mean difference) sebesar 20,19 menunjukkan adanya perbedaan hasil skor pengujian antara model PBT dan CBT yaitu 69,45 untuk PBT dan 49,269 untuk CBT. 
Maka secara umum dapat disimpulkan bahwa butir soal yang sama bila dikerjakan dengan metode CBT akan dirasakan lebih sulit oleh peserta tes dibandingkan dengan apabila dikerjakan dengan metode PBT.

Hasil analisis menunjukkan bahwa dimungkinkan terdapat perbedaan hasil skor pengujian bila suatu paket soal yang sama ditampilkan dengan model PBT dan model CBT. Hasil kajian penelitian ini menunjukkan bahwa paket soal yang ditampilkan pada layar monitor perangkat lunak CBT dengan menggunakan mouse dan keyboard mempunyai tingkat kesukaran yang berbeda ketika disajikan pada lembaran kertas dengan menggunakan pensil.

Selain perbedaan aspek konteks dan suasana, faktor belum terbiasanya siswa mengerjakan soal dengan model pengujian berbasis komputer dapat mengakibatkan terjadinya perbedaan hasil skor pengujian antara model PBT dan CBT. Pada umumnya, belum banyak sekolah yang menerapkan model pengujian berbasis komputer pada praktek pembelajaran di kelas-kelas. Jumlah laboratorium komputer umumnya tidak sebanding dengan kebutuhan keseluruhan jumlah siswa.

Mempunyai kemampuan dasar mengoperasikan perangkat komputer belum menjadi jaminan bahwa siswa telah terbiasa dengan model pengujian berbasis komputer. Hal tersebut mengingat bahwa kebiasaan menggunakan pengujian dengan media kertas telah berlangsung sebelumnya selama bertahun-tahun, sedangkan sosialisai pengujian dengan menggunakan komputer umumnya hanya dilaksanakan hitungan waktu beberapa bulan Dimungkinkan ada hambatan secara psikologis sehingga mempengaruhi adanya hasil perbedaan dari model pengujian PBT dan CBT. Ketidakbiasaan mengerjakan ujian berbasis komputer membuat siswa tidak mampu menunjukan kemampuan terbaiknya saat mengerjakan ujian. Faktor kebiasaan siswa mengerjakan butir soal dengan menggunakan model PBT tanpa disadari mempunyai pengaruh yang kurang mendukung bila menggunakan model pengujian berbasis komputer.

Pada penggunaan CBT perlu diperhatikan aspek computer selfefficacy yaitu seberapa percaya diri seorang siswa melihat dirinya dapat sukses dalam mengerjakan tes berbasis komputer. Computer self-efficacy membantu menurunkan tingkat kecemasan siswa dalam mengikuti ujian berbasis komputer [6] [7] [8]. Dengan berkurangnya tingkat kecemasan, siswa dapat lebih fokus untuk mengerjakan soal dan dapat menunjukan kemampuan terbaiknya. Di sisi lain, salah satu cara untuk mengurangi kegelisahan ujian (test anxiety) menggunakan komputer yaitu dengan meningkatkan pengalaman komputer siswa dan kepercayaan dirinya dalam mengikuti ujian berbasis komputer [9] [10]. Cara terbaik yaitu dengan mengoptimalkan masa persiapan. Memberikan kesempatan kepada siswa agar terbiasa dengan model CBT adalah penting [11]. Membiasakan siswa dengan memperbanyak uji coba model CBT sebelum hari tes dapat mengurangi faktor kecemasan.

Pada penggunaan CBT perlu diperhatikan aspek computer selfefficacy yaitu seberapa percaya diri seorang siswa melihat dirinya dapat sukses dalam mengerjakan tes berbasis komputer. Faktor computer self-efficacy ini berperan penting dalam menentukan keberhasilan siswa dalam ujian yaitu untuk menurunkan tingkat kecemasan siswa dalam mengikuti ujian berbasis komputer. Dengan berkurangnya tingkat kecemasan, siswa dapat lebih fokus untuk mengerjakan soal dan dapat menunjukan kemampuan terbaiknya. Harapannya, hasil ujiannya dapat lebih maksimal.

Di sisi lain, salah satu cara untuk mengurangi kegelisahan ujian menggunakan komputer yaitu dengan meningkatkan pengalaman komputer siswa dan kepercayaan dirinya dalam mengikuti ujian berbasis komputer. Cara terbaik yaitu dengan mengoptimalkan masa persiapan. Membiasakan siswa dengan memperbanyak pengalaman mengerjakan model CBT sebelum hari tes mungkin dapat mengurangi faktor kecemasan. Membiasakan siswa dengan ujian berbasis komputer akan bermanfaat bagi siswa yang kurang mampu secara ekonomi dan tidak memiliki komputer di rumah untuk meningkatkan pengalaman mengoperasikan komputernya.

Dari hasil kajian penelitian ini, secara praktis dapat digunakan sebagai indikator untuk menentukan tingkat kebiasaan siswa menggunakan peralatan komputer sebagai media pengujian. Tingkat kebiasaan siswa menggunakan peralatan komputer menentukan sejauh mana tingkat kesiapan siswa pada suatu sekolah sehubungan penggunaan media komputer sebagai alat bantu pengujian. Selama ini belum ada metode yang praktis dan sederhana untuk menentukan apakah siswa suatu sekolah telah siap menggunakan peralatan komputer untuk menggantikan model pengujian berbasis kertas.

Kajian penelitian ini memberikan landasan teori bahwa salah satu indikator kesiapan siswa menggunakan media komputer sebagai peralatan pengujian (model pengujian CBT) untuk menggantikan media kertas (model pengujian PBT) yaitu dengan membandingkan hasil skor pengujian antara metode pengujian PBT dan CBT. Jika perbandingan hasil skor pengujian yang dihasilkan pada model pengujian PBT dan CBT tidak didapatkan perbedaan yang signifikan, maka hal itu berarti bahwa peserta tes merasakan suasana yang sama walaupun berbeda model pengujian. Peserta tes tidak terpengaruh ketika menghadapi model pengujian PBT ataupun CBT. Peserta tes dinyatakan sudah mempunyai tingkat kebiasaan menggunakan komputer yang cukup. Pada kriteria ini peserta tes tidak merasakan adanya beban psikologis perbedaan model pengujian dari berbasis kertas menjadi berbasis komputer.

Jika perbandingan hasil nilai yang dihasilkan pada model pengujian PBT dan CBT didapatkan perbedaan yang signifikan, maka hal itu berarti bahwa peserta tes merasakan suasana yang berbeda saat mengerjakan soal yang sama antara model PBT dan CBT. Jika didapatkan rerata hasil nilai pada model PBT lebih besar dari rerata hasil nilai pada model CBT, maka peserta tes dinyatakan belum mempunyai tingkat kebiasaan yang baik dalam menggunakan komputer. Pada kriteria ini peserta tes masih merasakan adanya beban psikologis perbedaan model pengujian dari berbasis kertas menjadi berbasis komputer.

Namun, jika didapatkan rerata hasil nilai pada model PBT lebih rendah dari rerata hasil nilai pada model CBT, maka berarti bahwa peserta tes dinyatakan sudah mempunyai tingkat familiaritas yang tinggi dalam menggunakan komputer. Pada kriteria ini peserta tes sudah tidak mempunyai beban psikologis perbedaan model pengujian dari berbasis kertas menjadi berbasis komputer. Peserta tes bahkan telah merasakan adanya kemudahan pengujian menggunakan komputer dibandingkan dengan menggunakan media kertas dikarenakan komputer mempunyai fasilitas-fasilitas yang menguntungkan dan mempermudah proses pengerjaan pengujian..

Walaupun dapat menjadi indikator kesiapan peserta tes dalam hal penggunaan media pengujian berbasis komputer, namun tidak berarti akan sukses dan mendapatkan nilai ujian yang tinggi bila dilakukan model pengujian berbasis komputer. Strategi tersebut hanya sebagai indikator kesiapan penggunaan komputer sebagai sarana media pengujian. Untuk mendapatkan hasil yang tinggi pada pengujian berbasis komputer tentunya tetap difokuskan pada aspek konten materi proses pembelajarannya.

\section{IV.KESIMPULAN}

Dari hasil kajian dan analisis secara teori klasikal diperoleh kesimpulan bahwa dimungkinkan secara statistik terdapat perbedaan hasil nilai bila butir soal tersebut ditampilkan dengan model Paper Based Test (PBT) dan model Computer Based 
Testing (CBT). Perbedaan hasil skor pengujian pada model pengujian antara PBT dan CBT dapat dijadikan sebagai indikator untuk melihat tingkat kesiapan peserta tes dalam menghadapi ujian berbasis komputer.

Dengan membandingkan hasil nilai pada model pengujian antara PBT dan CBT secara statistik diperoleh 3 (tiga) kemungkinan yang dapat dipakai sebagai indikator tingkat kesiapan peserta tes, yaitu: (1) Jika tidak terdapat berbedaan hasil skor pengujian yang signifikan, maka rerata tingkat kesukaran butir pada model PBT setara dengan rerata tingkat kesukaran butir pada model CBT. Peserta tes dinyatakan telah siap menggunakan metode pengujian berbasis komputer, (2), Jika terdapat berbedaan hasil skor pengujian secara signifikan dan rerata hasil nilai model PBT lebih rendah dari CBT, maka peserta tes dinyatakan sangat siap menggunakan metode pengujian berbasis komputer, dan (3) Jika terdapat berbedaan hasil skor pengujian secara signifikan dan rerata hasil skor pengujian model PBT lebih tinggi dari CBT, maka peserta tes dinyatakan belum siap menggunakan metode pengujian berbasis komputer. Dalam hal ini peserta tes membutuhkan lebih banyak kesempatan lagi membiasakan diri menggunakan model pengujian berbasis komputer agar tingkat kesiapannya meningkat.

Perlunya kajian lebih lanjut untuk menganalisis keterkaitan hubungan tingkat pengetahuan dasar dan tingkat keterbiasaan peserta tes terhadap pengoperasian komputer dengan indeks kesukaran butir soal pada model pengujian PBT dan CBT agar dapat menjadi landasan bidang psikometri untuk memahami adanya kecenderungan perbedaan hasil skor pengujian pada model pengujian PBT dan CBT. Saran untuk pihak sekolah agar dapat memberikan sosialisasi pada para siswanya agar diberikan lebih banyak pengalaman untuk membiasakan diri menghadapi model pengujian berbasis komputer

\section{DAFTAR PUSTAKA}

[1] Bugbee, A. C. (1996). The equivalent of paper-and-pencil and computer-based testings. Journal of Research on Computing in Education, 28(3), pp. 282-299. Diakses pada tanggal 10 Pebruari 2020 dari laman https://doi.org/10.1080/08886504.1996.10782166

[2] Syahrul. (2018). Penyelenggaraan pengujian berbasis komputer dalam lingkup dunia pendidikan di Indonesia: Perkembangan, tantangan, dan arah inovasinya di masa depan. Pidato Pengukuhan Jabatan Profesor. Disampaikan pada Sidang Terbuka Luar Biasa Senat UNM, 25 April 2018

[3] Suhardi, Iwan (2017). Pengembangan Model Bank Soal Mata Pelajaran Bahasa Indonesia di Sekolah Lanjutan Indeks Atas dengan Tampilan Multi Media untuk Peniliaan Berbasis Computerized Adaptive Testing. Disertasi Doktor, tidak diterbitkan, Program Pascasarjana Universitas Negeri Yogyakarta.

[4] Rudner, M. L. (1998). An on-line, interactive, computer adaptive testing tutorial [Versi elektronik]. Diambil pada tanggal 20 November 2011 dari http://EdRes.org/scripts/cat.

[5] Grist, S. (1989). Computer adaptive tests. ERIC Digest No. 107 [Versi elektronik]. ERIC Clearinghouse on Tests Measurement and Evaluation Washington DC, American Institutes for Research Washington DC. Diambil pada tanggal 20 November 2011 dari http://files.eric.ed.gov/fulltext/ ED315425.pdf

[6] Compeau, D.R., \& Higgins, C. A. (1995). Computer self - efficacy: development of a measure and initial test. MIS Quarterly. 19 (2), pp. 189-211. Diakses pada tanggal 10 Pebruari 2020 dari laman https://pdfs.semanticscholar.org/391d/d4ca2ee3b2995260425d09dd9 7d4d9aaac29.pdf

[7] Surej, P.J. (2013). Influence of computer self-efficacy on information technology adoption. International Journal of Information
Technology, Vol. 19, No. 1, 2013. Diakses pada tanggal 10 Pebruari 2020 dari laman. http://intjit.org/cms/journal/volume/19/1/191_2.pdf

[8] Sam, H. K., Othman, A. E. A., \& Nordin, Z. S. (2005). Computer Self-Efficacy, Computer Anxiety, and Attitudes toward the Internet: A Study among Undergraduates in Unimas. Educational Technology \& Society. 8 (4), pp. 205-219. Diakses pada tanggal 10 Pebruari 2020 dari laman https://www.j-ets.net/ETS/journals/8_4/19.pdf

[9] Zeidner, M. \& Matthews, G. (2003). Test Anxiety. Encyclopedia of Psychological Assessment. SAGE Publications Ltd. pp: 965-969. Print ISBN: 9780761954941. Online ISBN: 9780857025753 Diakses pada tanggal 10 Pebruari 2020 dari laman DOI: http://dx.doi.org/10.4135/9780857025753.n202.

[10] Liebert, R.M., \& Morris, L.W.(1967). Cognitive and emotional components of test anxiety: a distinction and some initial data. Psychological Reports 20975-978. Diakses pada tanggal 10 Pebruari 2020 dari laman http://dx.doi.org/10.2466/pr0.1967.20.3.975

[11] Russell, M. (1999). Testing on computers: A follow-up study comparing performance on computer and on paper. Education Policy Analysis Archives, 7, 20. Diakses pada tanggal 10 Pebruari 2020 dari laman https://doi.org/10.14507/epaa.v7n20.1999. 